\title{
Global Warming and the G22 Nations: On the Failure of the Unfecc and Chaos Theory
}

\author{
Jan-Erik Lane \\ Correspondence: Jan-Erik Lane, Fellow with Public Policy Institute, Belgrade; 10 Charles Humbert, 1205 Geneva, 559 \\ A, 3rd Floor, Thuya Street, 9th Quarter, Yangon, Myanmar.
}

Received: December 13, 2017

doi:10.11114/aef.v5i2.2899
Accepted: December 25, 2017 Available online: December 28, 2017

URL: https://doi.org/10.11114/aef.v5i2.2899

\begin{abstract}
Economic outcomes tend to be best when there is no market failure, the standard textbook teaches us. Yet, the global economy in a broad sense, covering all consumers, firms and households is today plagued by externalities and free riding, as benefits from and costs for greenhouses gases are not tied together (Stern, 2007, 2015). Neither the UNFCCC nor the IPCC delivers real policy implementation against climate change (Conka, 2015; Vogler, 2016). This common pool regime (CPR) has too many members, resulting in transaction costs skyrocketing. It confounds sustainable development in general with specific anti-global warming policy-making and implementation of real results. The focus should be on the G20 countries plus Iran, as they are responsible for more than 2/3ds of all CO2s.
\end{abstract}

Kewwords: G20 groups of nations, de-carbonisation, COP21: GOAL I, II and III, solar power parks greenhouse gases (GHG), chaos theory

\section{Introduction}

The global governance of climate change issues has been entrusted the UN and its bodies, like the UNFCCC and the IPCC . This has been conducive to the mixing of global warming with the ideas of sustainable development. engaging all UN member states. I will argue that this is extremely unfortunate, as the UN bodies dealing with the issues are simple too big - transaction costs heavy. And global warming policy should be conducted by the countries that are mainly responsible, namely the G20 nations.

Moreover, the various sustainable development goals mention climate change as one of them, but for mankind it is of overwhelming importance. The concrete COP21 Treaty objectives do not at all mention al there developmental goals of sustainability, but centers upon global de-carbonisation. Only the G20 nations can achieve that, because they are responsible for almost 80 per cent of the greenhouse gases (GHG).

\section{Decarbonisation Goals and Sustainable Development}

The G20 nations almost perfectly coincide with the list of heaviest GHG or CO2 polluters. One needs to add Iran and delete Argentina. Among the largest polluters, we find international air traffic and international shipping, on the increase year in and year out, especially air traffic.

The global de-carbonisation plan according to the COP21 Agreement from Paris 2015 sets out a set of three stages and one mechanism to promote renewables or atomic power. Thus, we have:

1) Halting the $\mathrm{CO} 2$ increases in all countries by 2020 (GOAL I);

2) Reducing the $\mathrm{CO} 2 \mathrm{~s}$ by some 30 per cent by 2030 or more (GOAL II);

3) Achieve 75 per cent CO2 reductions by around 2080 (GOAL III);

4) Setting up of a Super Fund - 100 billion $\$ / y e a r-$ to assist countries in energy transformation away from fossil fuels.

These four elements - objectives and mechanism - above make for a realistic plan for global de-carbonisation in the $21^{\text {st }}$ century, saving mankind from Hawking irreversibility. But is it really implementable, given the typically egoistic incentives of countries and their governments? And what is the set of management strategies to be employed with the Super Fund. Not much progress has been accomplished by the UNFCCC since the Paris Treaty as far as implementation is concerned, although a few giant solar power parks have been constructed.

The UN Sustainable Development Goals are almost entirely different, with only (13), (14) and (15) being related to (7), 
clean energy.
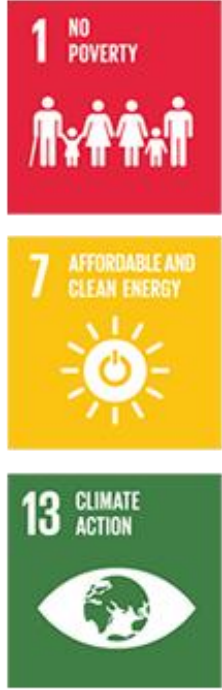
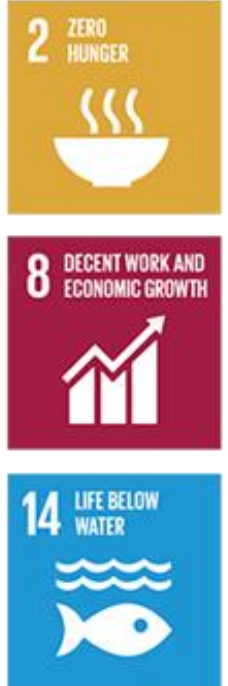
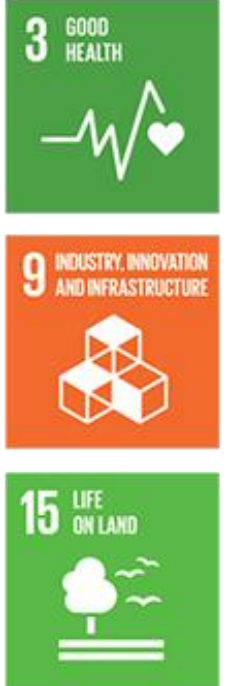
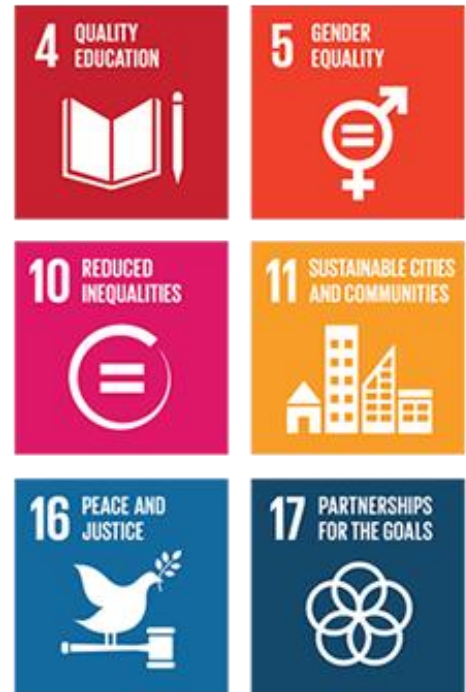
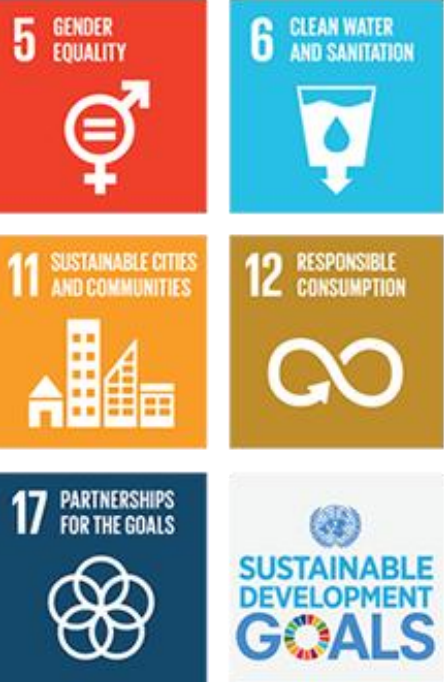

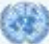

SUSTAINABLE DEVELOPMENT GOALS

Source: UNDP.

These goals are NOT realistic, especially as humanity keeps increasing. We know of no socio-economic system that can accomplish these objectives.

In the global warming discussion, there has been a tendency to conflate sustainable development with climate change (Sachs, 2015), in an effort to "fix" everything in one set of global UN policies: climate, justice, poverty, etc. This is very unfortunate, because it is merely utopian.

Climate change should be counter-acted by specific policies related to energy demand and supply by the main GHG polluters of the planet Earth, namely the G20 nations. This group can handle transaction costs, which the UN cannot.

\section{Implementation of Energy Policy: Wildavsky's Hiatus}

Basically, the global warming problematic is one issue, namely the anthropogenic sources of GHGs, stemming from energy consumption in a wide sense in all areas of human activity and social systems, from households over transportation to industry and agriculture. The energy-emission conundrum concerns the use of energy for generating affluence with attending emissions of $\mathrm{CO} 2 \mathrm{~s}$, methane, etc.

Burning fossil fuels is today essential for affluence and wealth, being vital to poor and rich countries. If energy consumption is reduced, economic recession and mass poverty would follow rapidly as well as of course also unemployment writ large social unrest. Planet Earth consumes simply far too much energy from burning the fossil fuels - see Table 1.

Table 1. Energy 2015 (Consumption in Million Tons of oil equivalent)

\begin{tabular}{lll}
\hline & Total & $\%$ \\
\hline Fossil fuels & 11306,4 & 86,0 \\
Oil & 4331,3 & 32,9 \\
Natural Gas & 3135,2 & 23,8 \\
Coal & 3839,9 & 29,2 \\
Renewables & 1257,8 & 9,6 \\
Hydroelectric & 892,9 & 6,8 \\
Others & 364,9 & 2,8 \\
Nuclear power & 583,1 & 4,4 \\
Total & 13147,3 & 100,0 \\
\hline
\end{tabular}

Source: BP Statistical Review of World Energy 2016

The hope that the augmentation of $\mathrm{CO} 2 \mathrm{~s}$ would "stall" has been nurtured widely, but now China reports ominously that its $\mathrm{CO} 2 \mathrm{~s}$ are set to increase again for a few years. Thus, Figure 1 may lead to the planet not fulfilling even COP21 GOAL I in 2020. 
World GDP - CO2 Emissions 1990 - 2016

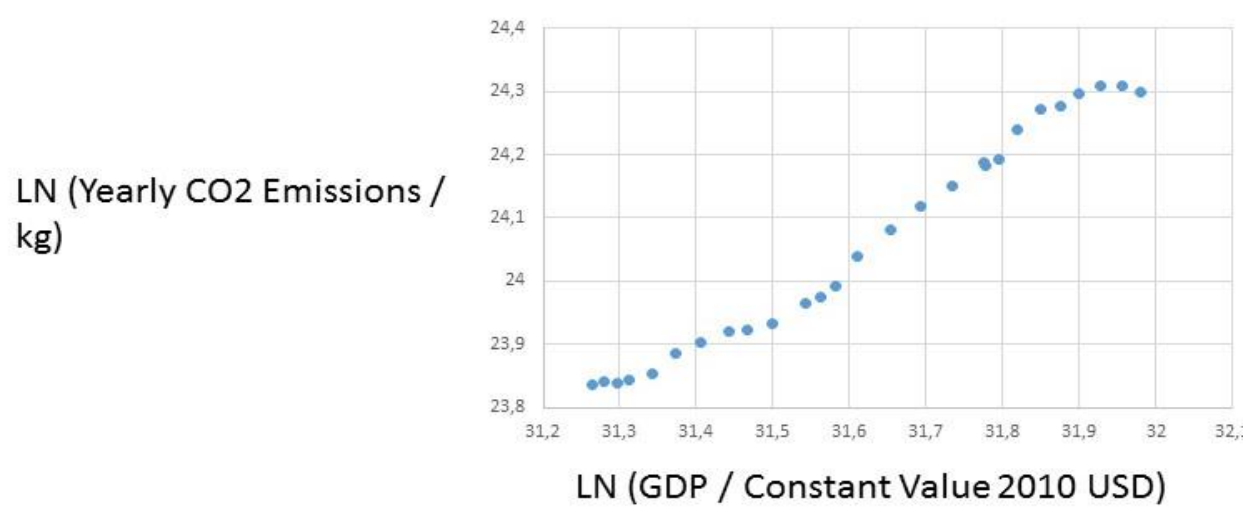

Figure 1. GDP-CO2s 1990-2016

Source: see References

GDP increases with the augmentation of energy per capita. De-carbonisation is the promise to undo these dismal links by making GDP and energy consumption rely upon carbon neutral energy resources, like modern renewables and atomic energy can this promise be kept or fulfilled? Figure 2 shows the almost iron law type link.

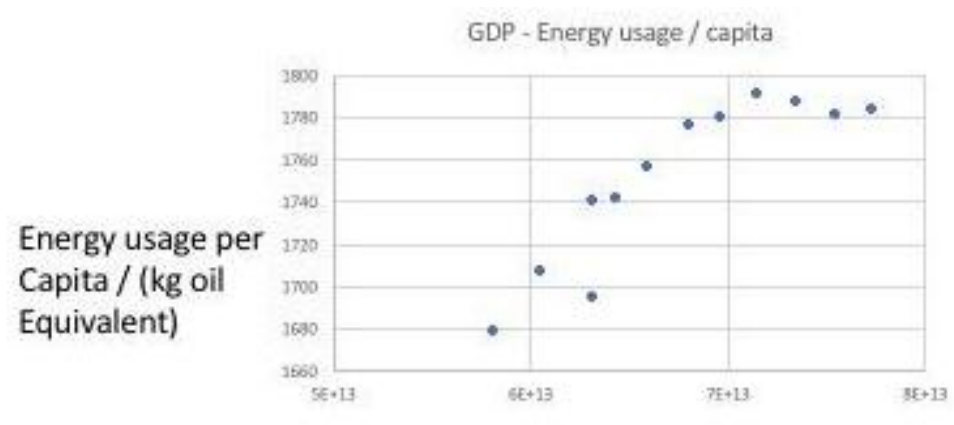

GDP / (Constant value 2010 USD)

Figure 2. GDP against energy per person, 2005-2016

Source: See References

Given the fact that the global economy depends to almost 90 per cent upon fossil fuel energy, as well as plans for another 20-30 per cent augmentation in energy demand for the next 30 years, the conclusion is that energy transformation is of utmost urgency, Global governance has fixed the objectives - GOAL I, II and III - but knows not how to implement them.

Enter Wildavsky: Although it was well-known in public administration and policy analysis that government policy-making could be flawed, incoherent and even erroneous in its empirical assumptions, it was a small chock when Wildavsky came along saying that policies often fail in the implementation stage. It is what happens AFTER the key decisions on policy that matters most for policy success or failure (Pressman and Wildavsky, 1984). Very often, policy execution fails to achieve the objectives. Policies may turn out to be counter-productive, promoting entirely different or opposite goals.

The COP21 process has yet to begin policy implementation. And the great danger is defection by the members of this Agreement on a gigantic CPR - common pool regime. Reneging in this Ocean PD game may concern contribution to the Super Fund or inability or unwillingness to fulfill the COP21 obligations: GOAL I, II and III.

\section{GHGs, Methane Emission and Chaos Theory}

There are several types of GHGs, but the UNFCCC has concentrated upon the carbon dioxide particles (CO2s). They are considered responsible for the human induced temperature rise that is global warming. It is true that the $\mathrm{CO} 2 \mathrm{~s}$ constitute the largest part of the GHCs.

But halting the increase in $\mathrm{CO} 2 \mathrm{~s}$ is far from enough to halt global warming. As long as the countries in the world have 
large positive outflows of $\mathrm{CO} 2 \mathrm{~s}$, the risks of climate change augment. Methane emissions are now becoming more frequent and important for global warming. Thus, we have several greenhouse gases, but the two biggest are the $\mathrm{CO} 2 \mathrm{~s}$ and methane. Finally, we have the Nitrous Oxide (fertilizers) and very small amounts of F-gases. Methane and F-gases are more powerful in preventing sun radiation to exit the Planet, but they are not as long lasting as the CO2s. The oceans swallow much CO2s, but this leads to acidification. Air conditioning uses F-gases - a positive feedback loop. Methane emissions will increase significantly in the next decades, as the permafrost melts. Below is Florent Dieterlen's calculation of the rise of methane emissions in Figure 3 (see papers by lane and Dieterlen 2017).

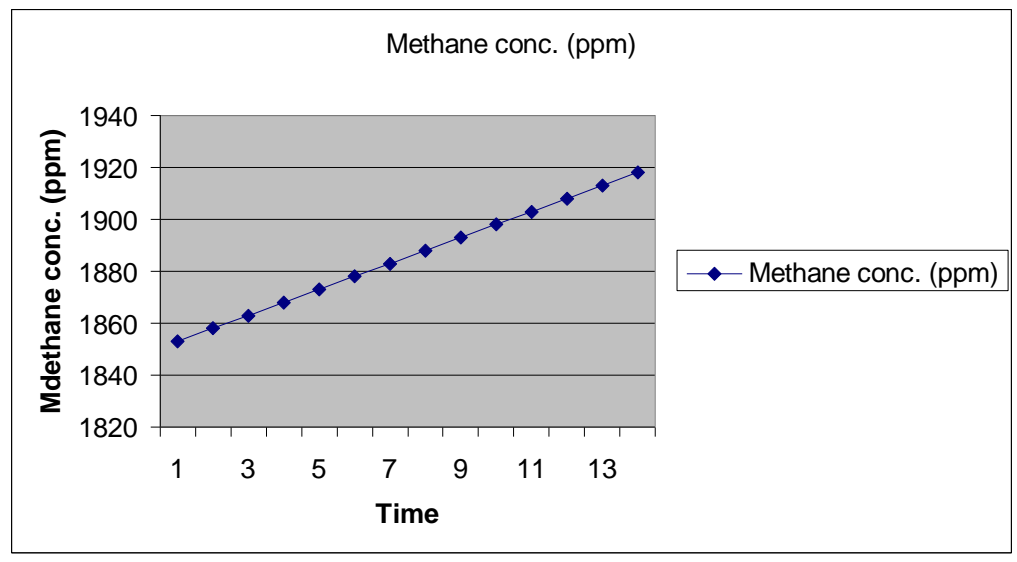

Figure 3. Methane emissions in Dieterlen's projection

Source: see references

With methane emissions rising, it is all the more urgent to considerably reduce $\mathrm{CO} 2$ emissions. Can all nations do it? Any decrease in methane concentration is improbable, due to: Agriculture emissions, as the temperature increase the metabolism of microbes in rice agriculture; Wetlands emissions do not diminish with the microbial chemical activity on increase; Fossil fuel production especially LGN; Forests diminish in the tropics, resulting in a decrease in animal or vegetal resources; Melting permafrost releases methane from land and see.

Globalwarm9ing will turn into chaos at the Hawking irreversible point in time, because we will have to face:

1) sharp temperature variations at various locations on planet Earth, like the North and South poles,

2) grave sudden impacts, like permafrost melting releasing methane,

3) powerful positive feedback lopes, like methane emissions augmenting the speed of temperature rise, which in turn melts more ice, making for ocean acidification, and huge land losses,

4) with all resulting in jumps in the Keeling curve.

We need to develop chaos modelling of how global warming impacts upon storms and wild fires, as well as dramatic increases in sea level rises in certain areas, like e.g. the Pacific Ocean region.

\section{Implementation Difficulties}

It is to be emphasized that global warming policy-making and policy implementation is about energy transformation de-carbonisation. It is not about global justice, income or wealth re-distribution, as well as poverty alleviation. Money from the Super Fund may certainly be employed for such purposes, sustainable development goals or even compensation for the ills of colonialism. If so, the UNFCCC will fail. One may also underline that climate change policies do not generally address environmental problems like "plasticization" of oceans and sees, reduction in endangered species or species loss.

The whole thing about halting global warming is to replace fossil fuels with modern renewables and nuclear power. Can the G20 nations do this according to the COP21 Treaty?

\subsection{Asian Great Miracles}

The fate of global de-carbonisation hinges upon policy implementation in three giant Asian countries, all committed to catch-up strategies of quick socio-economic development, using energy. They are China, India and Indonesia.

\section{China}

Very recent information says that China, the biggest emitter of $\mathrm{CO} 2 \mathrm{~s}$, will not succeed to halt its curve for $\mathrm{CO} 2 \mathrm{~s}$. Instead, it counts upon some 3 per cent increases the nearest years - see Figure 4. 
GDP - CO2 Emissions for China 1990 - 2016

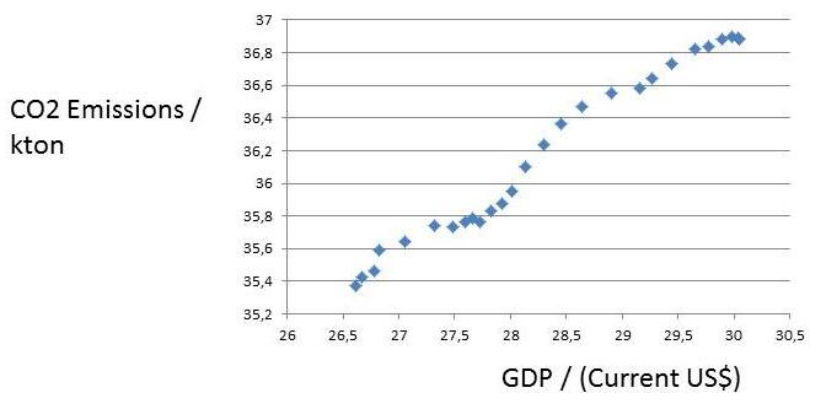

Figure 4. China: GDP and CO2s: $y=0,46 x, R^{2}=0,98$

China has officially declared that it intends to meet both COAL I, halting the increase in CO2s, and GOAL II, reducing $\mathrm{CO} 2 \mathrm{~s}$ by some 30 per cent. But promises and intensions are one thing, real life developments another matter. All countries in this CPR can at any time renege, the US has already done. If China too defects, then we have Hawking irreversibility.

China promises to reduce is GHGs, especially the lethal pollution in Beijing. But it also has great plans for future energy demands! It is true that China moves aggressively into new power sources: solar, wind and atomic power. But its ambitions for air traffic, car markets and the New Silk Road are daunting.

\section{India}

The upward sloping GDO-CO2 curve is strong for India. And India will not accept a trade-off between growth and $\mathrm{CO} 2 \mathrm{~s}$, putting the emphasis upon electrification of all households and poverty uplifting. Can and will India honour its de-carbonisation promises without generous Super Fund help?! Look at the present pattern of energy consumption (Figure 5).

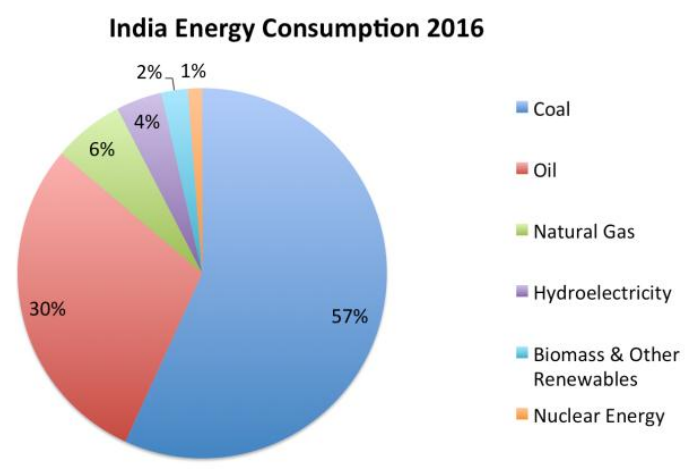

Figure 5. India

Fossil fuels, especially coal, dominate totally. In India, biomass is charcoal, more polluting than coal itself. India is completely out of tune with the COP21 objectives.

The Indian government engages much in energy planning with foreign expertise - see Indian Energy Outlook from 2015 by IEA. One scenario is portrayed in Figure 6.

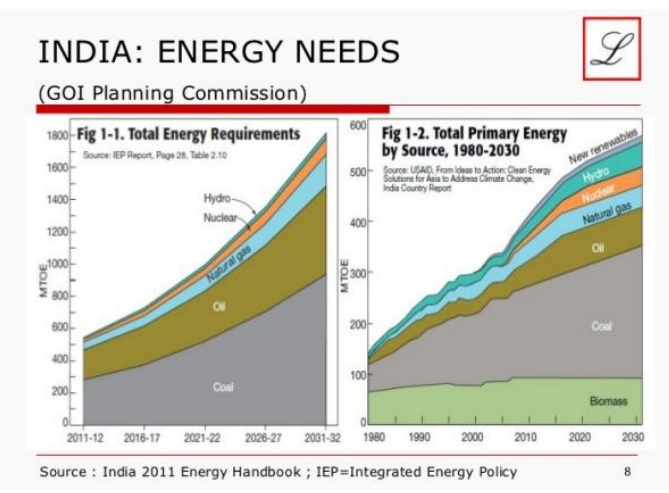

Figure 6. India 
https://www.slideshare.net/objectivecapital/india-growing-energy-needs-to-fuel-growth

The huge planned expansion in energy demand is not in agreement with global de-carbonisation plans. To reduce coal and charcoal dependency, India must turn to atomic and solar power. Hydro power requires safe access to water, which global warming may undo for Himalaya.

\section{Indonesia}

Indonesia, being a giant nation with economic growth and enormous forest burning, displays a strong upward trend in CO2s. What makes Indonesia so important for the implementation of global de-carbonisation according to the COP21 Treaty is not only is mega size in population, but also its rain forests in Kalimantan and Sumatra. The government has not been able to protect these global lungs, as they are cut down and burned for agriculture. It is true that renewables are planned to increase, but so is coal. Together with forest emissions, Indonesia has to renege, as the planning of the expansion of the energy sector - Figure 7 - shows little regard for COP21 objectives.

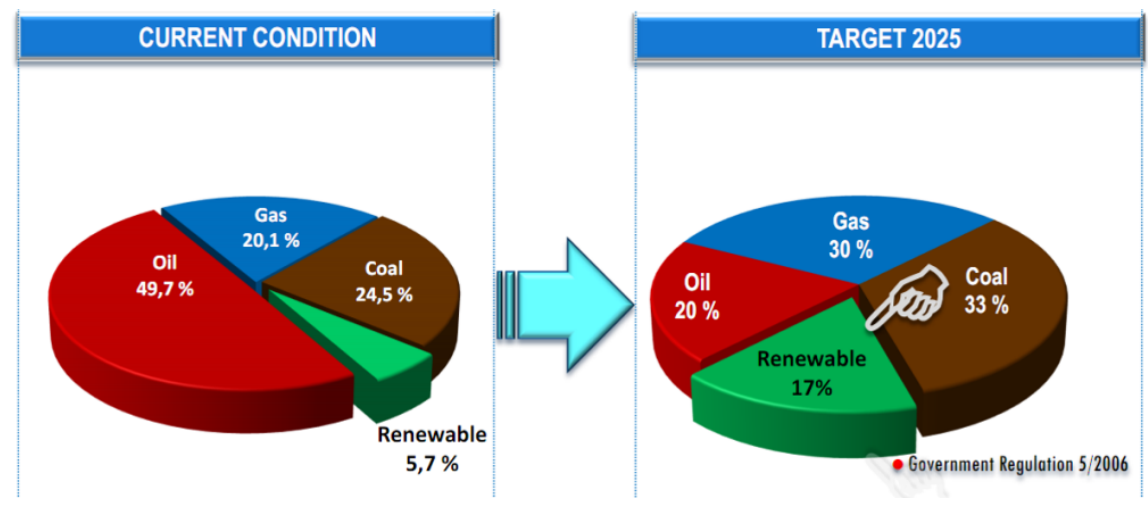

Figure 7. Indonesian energy mix

http://blogs.vertcaptech.com/2014/01/06/renewable-energy-potential-indonesia/\#.Wh_p6lWWbIU

\subsection{Ausralia's Intransigence}

Australia has always been negative to global de-carbonisaion, a least according to the prevailing attitude among its leading politicians. This stance reflects the country's total reliance on fossil fuels at home for energy, as well as its giant exports of fossil fuels to other countries, especially in the Asia-Pacific region. Australia is perhaps one of the most addicted to fossil fuels country in the world. However, its GDP-CO2 curve has recently stalled. The energy mix is presented in Figure 8.

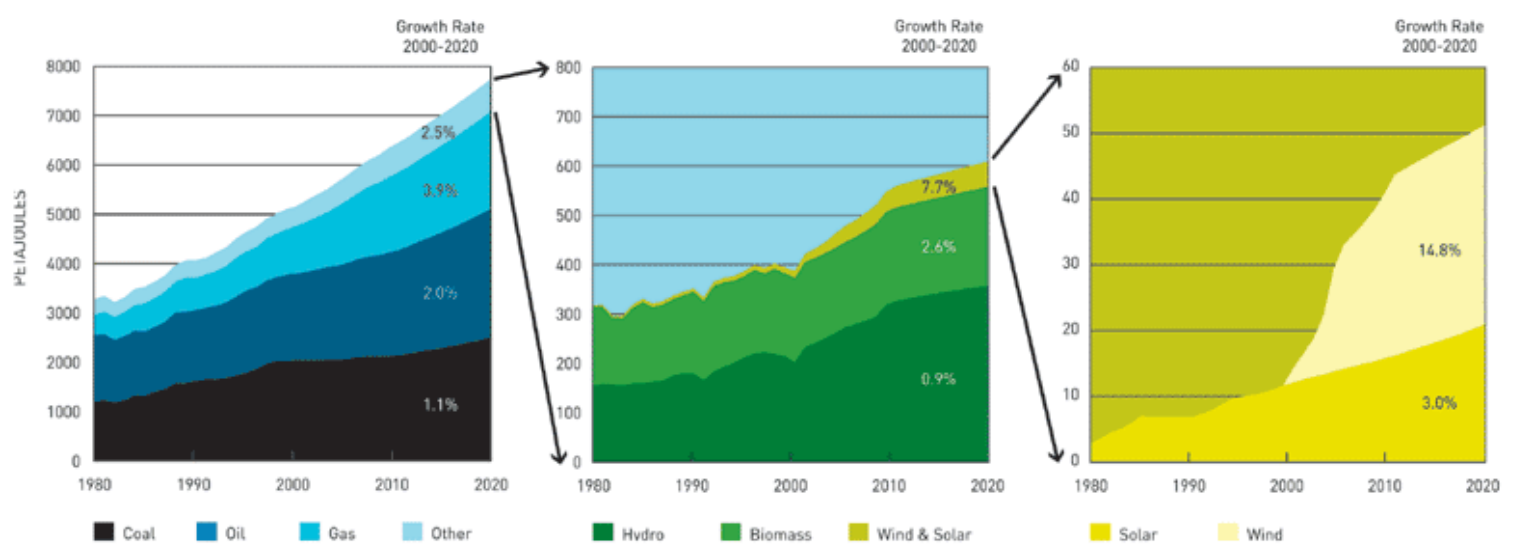

Figure 8. Energy plans for Australia

Source: https://www.energymatters.com.au/faqs/renewable-energy-faq/

Without a consistent policy reversal, Australia may be forced to renege upon de-carbonisation. "Our future lies in keeping increasing living standards", says PM Turnball, but more important for mankind is a stable atmosphere, generally speaking. With the planning in Figure 8, Australia will not comply with COP21.

\subsection{The Americas and Us Defection}

One may focus the interest in the Americas upon other big G20 nations than the US. But it may be said that the US now 
has a declining $\mathrm{CO} 2$ curve due to reduction in coal and increase in gas. It will fulfill GOAL I, but hardly GOAL II without policy changes/

In all the four giant nations - USA, Canada, Mexico and Brazil - the increases in CO2s have stalled. There is a slight decrease in GHGs, but methane emissions are increasing. Coal consumption is down and a variety of modern renewables have been put in place. All four would fulfill GOAL I in the COP21, but they are going to fail GOAL II. Each of these big nations has an Achilles heel when it comes to de-carbonisation.

\section{US $=$ Fracking}

When it is projected that the US will be a major exported of oil and gas around 2050, the source is fracking. It is already a considerable source of natural gas, helping to reduce coal consumption. But fracking is still carbonization, with increases in methane emissions. Figure 9 shows that the US will rely more upon natural gas than on renewables,

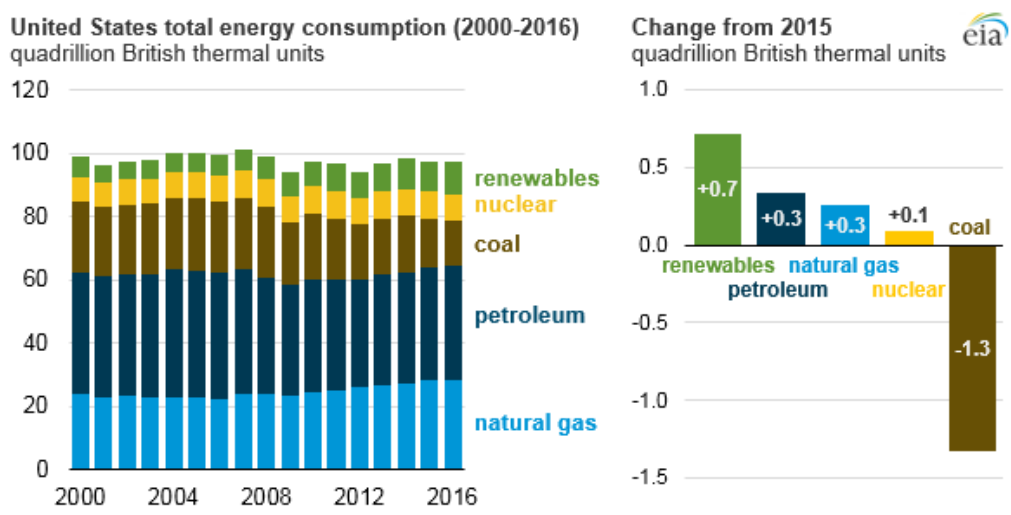

Figure 9. US energy mix

Source: https://www.eia.gov/todayinenergy/detail.php?id=30652

\section{Canada $=$ Oil Sands}

Canada enjoys massive amounts of hydro power, which will last as long global warming does not result in water shortages. It also invests heavily in wind power. But its great dependence on oil sands is not conducive to de-carbonisaion. The oil sand business is very dirty, polluting and expansive with pipeline to the US. Figure 10 would not pass GOAL II.

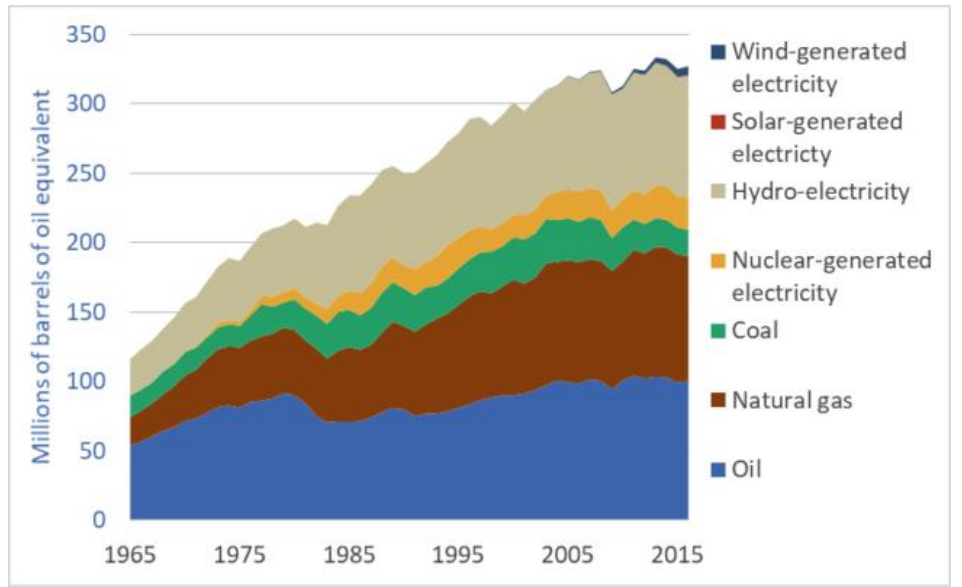

Figure 10. Canada energy mix

Source: http://www.darrinqualman.com/canadian-energy-use-data/

\section{Brazil = Energy expansion and Amazons?}

Brazil enjoys the benefit of access to various energy sources. At the same time it has a huge population with lots of poverty. This implies that socio-economic development has the greatest priority with Brazilian politicians. The outcome is the plan for a phenomenal increase in energy demand - see Figure 11. 

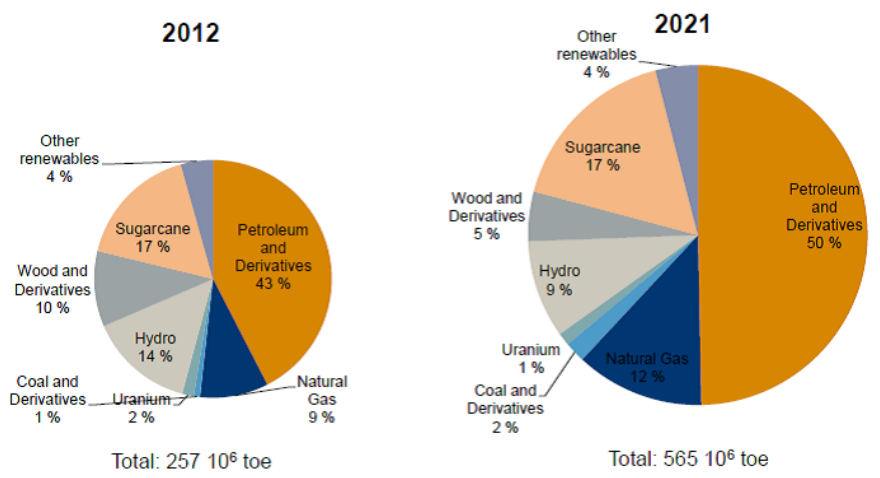

Figure 11. Brazil energy mix

Source: https://www.linkedin.com/pulse/focus-renewable-energy-technologies-brazil-luca-gautero

This is more than doubling of energy supply, confirming how important energy is for affluence. The key question is whether Brazil will turn a rapidly shrinking y of dams instead of putting the resources into solar power parks?

\section{Mexico= oil and gas!}

Here we have a typically carbonized country. Figure 12 shows that fossil fuels today account for around 90 per cent of energy consumption.

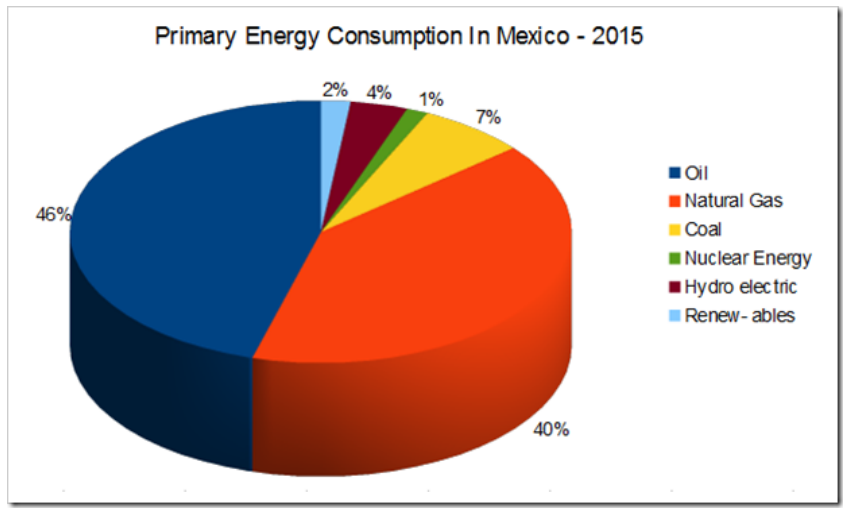

Figure 12. Mexico energy mix

Source: https://notalotofpeopleknowthat.wordpress.com/2016/09/26/mexico-to-start-fracking-next-year/

It is true that Mexican planning speaks much of renewables, but the distance to GOAL II is distant indees. Again, solar power would help Mexico de-carbonise.

\subsection{Middle East Oil and Gas}

In this region of the world, one set of countries possess enormous oil and gas reserves, and they are often very rich, if well-ordered societies. Another set of countries have to import fossil fuels. The Middle East is carbonized to nearly 100 per cent. And none of them could fulfill GOAL I AND GOAL II. See Saudi Arabia’s CO2sincrease in Figure 13.

GDP per capita - CO2 per capita Saudi Arabia 1990 - 2016

CO2 Emissions per capita I ton

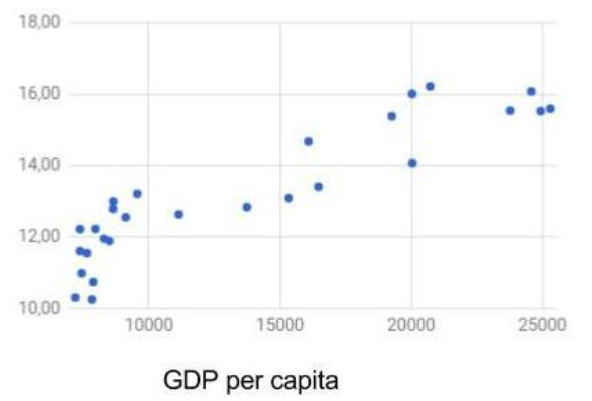

Figure 13. Saudi Arable GDP-CO2s 
Saudi Arabia only uses oil and gas. And why not? Yet, as partners in the COP21 club with its CPR of de-carbonisation, also the Saudis must change. To fulfil GOAL I and II, the new Saudi ruler has outlines an ambitious transformation plan, involving the turn to renewables and atomic power. It also involves the construction of cities, entirely energized by non-fossil energy sources. The Saudis can pay for all these magnificent plans, but global warming may make life in the Gulf difficult to support, as temperature rises and air conditioning fuels climate change.

The highest per capita $\mathrm{CO} 2$ emissions in the world are to be found in the Gulf, with UAE and Qatar. They have a life-style based on enormous energy consumption and pharaonic cement constructions. They say they want to de-carbonise too - solar power! But these Gulf plans are hardly credible.

Iran has been a sleeping giant for decades due to political and religious turmoil. It nourishes its large and fast growing population with oil and gas energy. To $\mathrm{CO} 2$ augmentation, it must turn to COP21 and follow its de-earbonisation plan: GOAL I and II.

GDP - CO2 Emissions Iran 1993 - 2015

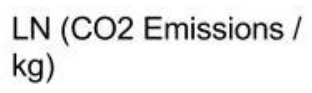

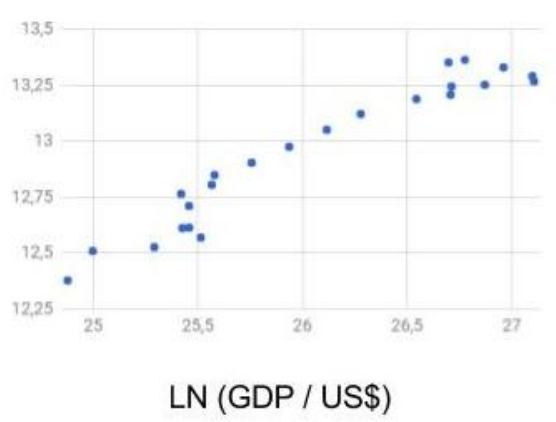

Figure 14. Iran GDP-CO2s

Coming out of isolation and representing Shia power in the region, Iran must be paid attention to, both politically and economically; it has the capacity to de-carbonise, using nuclear and renewable energy. This would require though more of stability in this region.

\subsection{European Hesitance}

The EU has pushed for anti-climate change policy-making for a long time. Most EU countries now have falling $\mathrm{CO} 2$ curves, reflecting a diversified energy supply - see Figure 15.

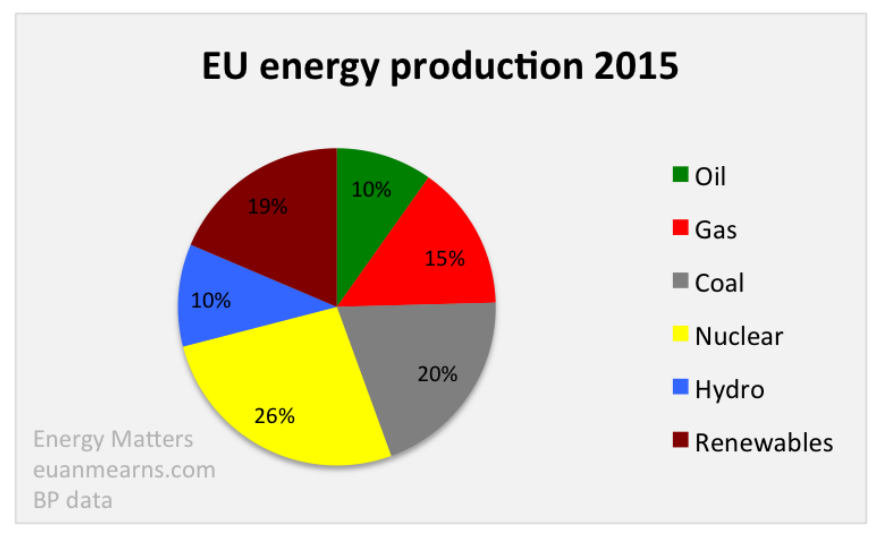

Figure 15. EU energy mix

However, the energy mix in various EU member states is highly different, as some rely much upon coal still. France has more than any country favoured atomic. Coal is burned in Eastern Europe and Germany. Natural gas is used in many countries, with imports from Russia and Algeria.

What is stunning in the EU energy policies is the plan to remove all coal and all nuclear power - see Figure16. 


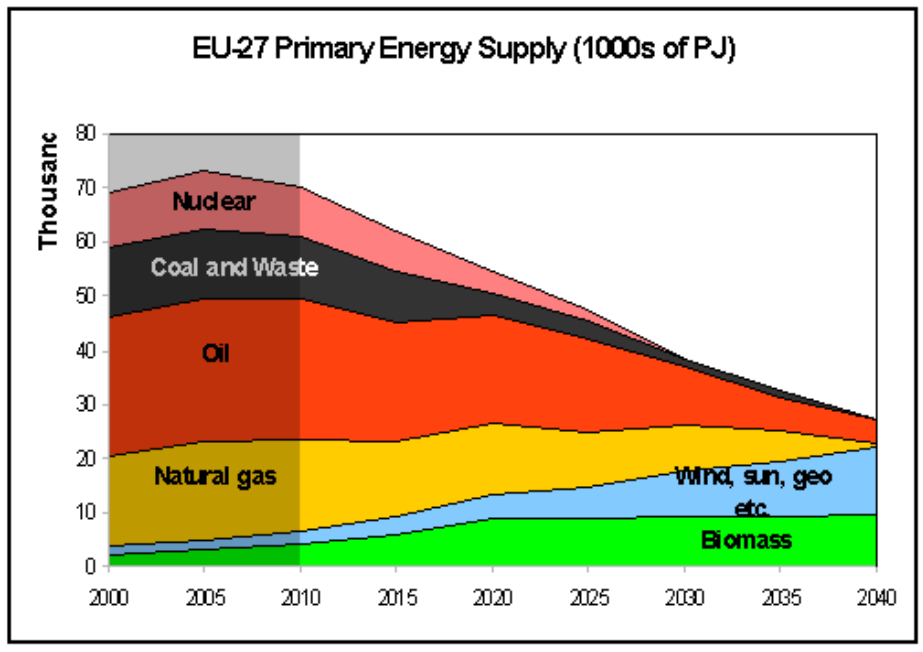

Figure 16. EU plans for de-carbonisation

Source: http://www.inforse.org/europe/VisionEU27.htm

But where is the supplementary energy going to come from? All energy from coal and atomic power must of course be replaced - HOW? Most nations count on retrieving more energy the coming decades, but not the EU according to Figure 16.

The Europeans have coupled de-carbonisation with the stop of atomic power, although these two energy kinds have nothing to do with each other. If halting climate change is the first priority because of urgency, then governments may use nuclear power, which also happens to be the case in several other countries. Global warming is more lethal than atomic power plants failure, especially if we pass Hawking irreversibility. Germany continues with coal (from Colombia!) but shuts down nuclear plants. France prefers to close nuclear plants ahead of updating them, making then safer. The question of final resting place for nuclear waste is most difficult, but climate change comes before in time. Abolishing coal and dismantling atomic power, the European will have to build many solar power parks.

\section{Solar Power Parks}

The Wildavsky hiatus - how to begin implementing the COP21 Treaty? The closer in time to 2020 we come, the larger the risk becomes for country defections. GOAL 1 has to be fulfilled by 2020. And then comes the much more difficult GOAL II, with substantial de-carbonisation. Removing atomic power is NOT a solution to climate change, nor is carbon sequestration, as the Asian Development Bank suggests in 2013 and 2017. Solar power and electrical vehicles!

Table 2 estimates how many solar power parks of the Moroccan size are needed to replace the energy cut in fossil fuels and maintain the same energy amount, for G20 countries with the largest $\mathrm{CO} 2$ emissions? 
Table 2. Number of Ouarzazate plants necessary in 2030 for COP21's GOAL II: (Note: Average of 250 - 300 days of sunshine used for all entries except Australia, Indonesia, and Mexico, where 300 - 350 was used)

\begin{tabular}{l|l|l|l}
\hline G 20 Nations & $\begin{array}{l}\text { Co2 reduction pledge / } \\
\text { \% of 2005 emissions }\end{array}$ & $\begin{array}{l}\text { Number of gigantic solar } \\
\text { plants } \\
\text { (Ouarzazate) }\end{array}$ & $\begin{array}{l}\text { Gigantic plants needed } \\
\text { for 40 \% reduction }\end{array}$ \\
\hline United States & $26-28^{1}$ & 2100 & 3200 \\
\hline China & None $^{2}$ & 0 & 3300 \\
\hline South Korea & 37 & 260 & 280 \\
\hline India & None & 0 & 600 \\
\hline Japan & 26 & 460 & 700 \\
\hline Brazil & 43 & 180 & 170 \\
\hline Indonesia & 29 & 120 & 170 \\
\hline Canada & 30 & 230 & 300 \\
\hline Mexico & 25 & 120 & 200 \\
\hline Australia & $26-28$ & 130 & 190 \\
\hline Russia & None & 0 & 940 \\
\hline Canada & 30 & 230 & 300 \\
\hline Mexico & 25 & 120 & 200 \\
\hline Saudi Arabia & None ii & 0 & 150 \\
\hline Iran & $4-12$ iv & 22 & 220 \\
\hline Argentina & None ii & 0 & 80 \\
\hline Italy & 351 & 230 & 270 \\
\hline Germany & $49^{45}$ & 550 & 450 \\
\hline France & 371 & 210 & 220 \\
\hline Turkey & 21 & 60 & 120 \\
\hline South Africa & & & \\
\hline World & N/A & N/A & 16000 \\
\hline
\end{tabular}

\section{Conclusion}

A realistic plan for halting global warming would include the following:

i) Focus first upon the G20 plus Iran;

ii) Close all coal plants up to 2020;

iii) Keep the existing nuclear power stations running;

iv) Start building solar power parks and wind power stations all over the world;

v) Turn then to the other countries - e.g. Chile, Paraguay, Egypt, Algeria Kenya, Pakistan, Thailand, Malaysia, Kazakhstan, etc. and help them close coal and charcoal down in order to concentrate upon solar power; Hand out small gas stoves to poor households in South Asia and Sub-Saharan Africa.

vi) Speed up the turn to electrical vehicles of all kinds.

vii) Build new atomic power plants with new safer technology;

viii) Use geo-thermal power extensively where possible;

ix) Maximise energy efficiency.

Global warming is so dangerous that it must the exclusive focus of he governments of the world, not to mix it up with UN development aims or general environmental concerns. The G20 groups of nations must go first in global de-carbonisation, closing all coal plants, replacing them with solar and atomic power, and start using electrical vehicles instead of SUVs.

\footnotetext{
${ }^{1}$ The United States has pulled out of the deal.

${ }^{2}$ No absolute target.

${ }^{3}$ Pledge is above current level, no reduction.

${ }^{4}$ Upper limit dependent on receiving financial support.

${ }^{5}$ EU joint pledge of $40 \%$ compared to 1990.
} 


\section{Reference}

\section{Sources}

Solar power:

Paris

2015

Tracking country

climate

pledges.

Carbon

Brief,

https://www.carbonbrief.org/paris-2015-tracking-country-climate-pledges

CO2 Emission Reduction With Solar, http://www.solarmango.com/in/tools/solar-carbon-emission-reduction

EDGAR v 4.3.2, European Commission, Joint Research Centre (JRC)/PBL Netherlands Environmental Assessment Agency. Emission Database for Global Atmospheric Research (EDGAR), release version 4.3.2. http://edgar.jrc.ec.europe.eu, 2016 forthcoming

GDP sources:

OECD National Accounts data files.

World Bank national accounts data - data.worldbank.org

GHG and energy sources:

BP Energy Outlook 2016.

British Petroleum Statistical Review of World Energy 2016

Energy Information Administration. Washington, DC.

EU Emissions Database for Global Research EDGAR, http://edgar.jrc.ec.europa.eu/

EU Joint Research Centre Emission Database for Global Atmospheric

International Energy Agency. Paris.

Research - http://edgar.jrc.ec.europa.eu/overview.php

UN Framework $\quad$ Convention $\quad$ on Change

http://unfccc.int/ghg_data/ghg_data_unfccc/time_series_annex_i/items/3814.php

World Bank Data Indicators, data.worldbank.org

World Resources Institute CAIT Climate Data Explorer - cait.wri.org

\section{Literature}

Conka, K. (2015). Un Unfinished Foundation. The United Nations and Global Environmental Governance. Oxford: OUP. https://doi.org/10.1093/acprof:oso/9780190232856.001.0001

Kaya, Y., \& Yokoburi, K. (1997). Environment, energy, and economy: Strategies for sustainability. Tokyo: United Nations University Press.

Ostrom, E. (1990). Governing the Commons. Cambridge: Cambridge U.P. https://doi.org/10.1017/CBO9780511807763

Pressman, J., \& Wildavsky, A. (1984). Implementation. Berkeley: University fo California Press.

Ramesh, J. (2015). Green Signals: Ecology, Growth and Democracy in India. Oxford: Oxford University Press. https://doi.org/10.1093/acprof:oso/9780199457526.001.0001

Sachs, J. D. (2015). The Age of Sustainable Development. New York: Columbia University Press. https://doi.org/10.7312/sach17314

Stern, N. (2007). The Economics of Climate Change. Oxford: OUP. https://doi.org/10.1017/CBO9780511817434

Stern, N. (2015). What are we waiting for? Cambridge, MA: MIT Press.

Vogler, J. (2016). Climate Change in World Politics. Basingstoke: MacmillanPalgraveP.

\section{Copyrights}

Copyright for this article is retained by the author(s), with first publication rights granted to the journal.

This is an open-access article distributed under the terms and conditions of the Creative Commons Attribution license which permits unrestricted use, distribution, and reproduction in any medium, provided the original work is properly cited. 